Institute of

Public Finance
NEWSLETTER

AN OCCASIONAL PUBLICATION OF THE INSTITUTE OF PUBLIC FINANCE

\title{
Impact of the European Semester on the Budgetary Process in Groatia
}

\author{
KATARINA OTT Institute of Public Finance
}

Year after year, the Ministry of Finance and governments are justly berated for not keeping to timetables, for unrealistic assumptions and the insubstantiality of the key documents (strategic plans, strategies and guidelines) meant to underpin the three-year budget. These shortcomings have led to frequent budget revisions and unsatisfactory fiscal outcomes. How is the entry of Croatia into the EU going to affect the economic policy and the public finances in the country? How will it be reflected in the budgetary process - from strategy and guidelines to budget plan? What exactly is going to happen when we do get into the EU? And what has already started to happen?

\section{EUROPEAN SEMESTER}

The economic crisis cast into sharp relief the need for a more powerful coordination of the economic policies of EU member states, for harmonisation of the processes and objectives of national budgetary policies and growth and employment policies. Operating since 2OII at EU level for this reason is the European Semester (shown in brief in table I), so called because the majority of the coordination cycle unfolds in the first six months each year. Members harmonise budgetary and economic policies with objectives and rules agreed at EU level so as to ensure sound public finances, to foster economic growth and prevent excessive macroeconomic imbalances. According to a set calendar they receive instructions, according to which they submit national programmes that are evaluated at EU level. After evaluation of national programmes, the member states receive individual recommendations for national budgetary policies and for reforms. If necessary, they are also sent recommendations for the correction of macroeconomic imbalances. The objective is for members to take into consideration recommendations when they define their budgets for the next year. 
Table I

The European Semester

\begin{tabular}{|c|c|}
\hline \multicolumn{2}{|c|}{ Preparatory phase } \\
\hline \multicolumn{2}{|c|}{ November and December } \\
\hline $\begin{array}{l}\text { European } \\
\text { Commission }\end{array}$ & $\begin{array}{l}\text { Publishes the Annual Growth Survey with its priorities for the forthcoming year } \\
\text { that member states have to take into account while planning the national } \\
\text { economic policy, and the Alert Mechanism Report concerning the macroeconomic } \\
\text { situations of the individual members, pursuant to which it can decide whether it } \\
\text { wants to conduct a more detailed survey of the situation in the members in which } \\
\text { the risk of potential macroeconomic imbalances seems high, and accordingly } \\
\text { make recommendations to the members. }\end{array}$ \\
\hline
\end{tabular}

First phase: Policy Guidelines at EU level

January and February

Council of the EU Debates the Annual Growth Survey and gives its opinion and makes recommendations.

\begin{tabular}{|c|c|}
\hline European Parliament & $\begin{array}{l}\text { Debates the Annual Growth Survey and gives opinions and recommendations, and } \\
\text { also gives an opinion on the Employment Guidelines. It can also invite } \\
\text { representatives of the Council of the EU, the European Council, the Commission } \\
\text { and individual member states to a debate on topics related to the European } \\
\text { Semester. }\end{array}$ \\
\hline \multicolumn{2}{|l|}{ March } \\
\hline European Council & $\begin{array}{l}\text { Pursuant to the Annual Growth Survey and the analyses and conclusions of the } \\
\text { Council of the EU, it presents policy directions. It requires member states to take } \\
\text { them into consideration in the preparation of the national stability or convergence } \\
\text { programmes that map out national budgetary policies and policies for fostering } \\
\text { growth and competitiveness. }\end{array}$ \\
\hline $\begin{array}{l}\text { European } \\
\text { Commission }\end{array}$ & $\begin{array}{l}\text { Publishes the results of surveys conducted in member states with a high risk of } \\
\text { macroeconomic imbalances, pursuant to which it can make recommendations to } \\
\text { members for their correction. }\end{array}$ \\
\hline \multicolumn{2}{|c|}{ Second phase: Objectives, policies and plans for individual member states } \\
\hline \multicolumn{2}{|l|}{ April } \\
\hline Member states & $\begin{array}{l}\text { Up to the I5th and at the latest by the } 30 \text { th of April submit national stability and } \\
\text { convergence programmes with medium term budgetary strategies and national } \\
\text { reform programmes with plans of structural reforms to stimulate growth and } \\
\text { employment. }\end{array}$ \\
\hline \multicolumn{2}{|l|}{ May } \\
\hline $\begin{array}{l}\text { European } \\
\text { Commission }\end{array}$ & $\begin{array}{l}\text { Evaluates national plans of member states and gives draft recommendations to each } \\
\text { individual member. }\end{array}$ \\
\hline \multicolumn{2}{|l|}{ June } \\
\hline Council of the EU & $\begin{array}{l}\text { Debates draft recommendations made to member states and agrees on final } \\
\text { recommendations for each individual member, which have to be supported by } \\
\text { the European Council. }\end{array}$ \\
\hline \multicolumn{2}{|l|}{ July } \\
\hline Council of the EU & $\begin{array}{l}\text { Adopts recommendations for every individual member, which is expected to } \\
\text { implement them. }\end{array}$ \\
\hline \multicolumn{2}{|c|}{ Third phase: Implementation } \\
\hline \multicolumn{2}{|l|}{ July } \\
\hline Member States & $\begin{array}{l}\text { take into account the recommendations in the process of national decision making } \\
\text { about the national budget for the following year that will enable them to carry out } \\
\text { the policies laid down. }\end{array}$ \\
\hline
\end{tabular}


The new European Semester cycle will start off again at the end of the year, when the European Commission publishes its Annual Growth Survey, with a review of the economic situation and an evaluation of the progress made by each member in implementing recommendations from the previous year's Semester.

\section{THE BUDGETARY PROGESS IN CROATIA}

Table 2 shows the Croatian budgetary process in the first half of the year.

\section{Table 2}

Croatian budgetary process in the first half of the year

\begin{tabular}{|c|c|}
\hline By mid-March & \\
\hline $\begin{array}{l}\text { The Ministry of Finance in collaboration } \\
\text { with the Ministry of Regional } \\
\text { Development and EU Funds }\end{array}$ & $\begin{array}{l}\text { Sends to ministries and other government bodies instructions for drawing } \\
\text { up strategic plans for a three-year period. }\end{array}$ \\
\hline \multicolumn{2}{|l|}{ By mid-April } \\
\hline Ministries and other government bodies & $\begin{array}{l}\text { Send the Ministry of Finance their own strategic plans for a three-year } \\
\text { period. }\end{array}$ \\
\hline \multicolumn{2}{|l|}{ By the end of April } \\
\hline $\begin{array}{l}\text { The Ministry of Finance and the Ministry } \\
\text { of Regional Development and EU Funds }\end{array}$ & Propose to the Government their strategy for a three-year period. \\
\hline \multicolumn{2}{|l|}{ By mid-May } \\
\hline The Government & Adopts its three-year strategy. \\
\hline \multicolumn{2}{|l|}{ By the end of May } \\
\hline The Ministry of Finance & Proposes to the Government its guidelines for economic and fiscal policy. \\
\hline \multicolumn{2}{|l|}{ By mid-June } \\
\hline The Government & Adopts the guidelines of economic and fiscal policy. \\
\hline \multicolumn{2}{|l|}{ By the end of June } \\
\hline The Ministry of Finance & $\begin{array}{l}\text { Supplies ministries and other government bodies at the sectional level } \\
\text { (organisational classification) as well extra-budgetary users instructions } \\
\text { for drawing up a proposal of the central government budget. }\end{array}$ \\
\hline
\end{tabular}

The instructions for drawing up strategic plans for the three-year period, which should have been sent by mid-March to the ministries and other government bodies, this year were published more than one month later, i.e. by the end of April. This dilatoriness is usual - last year, instead of by mid-March, it was done in April, and so all the next phases were late too. The Government did not manage to bring in the three-year strategy, which has to be adopted by mid-May, until midJuly, while guidelines for economic and fiscal policy, instead of by mid-June arrived only in August. And in consequence the instructions, proposals, drafts and finally the adoption of the budget were also postponed. Last year was by no means an exception; there have been years in which delays were considerably longer.

But the unpunctuality of the phases of the Croatian budgetary process is not its greatest shortcoming. More serious problems are the faulty strategies and plans, backed by defective macroeconomic assumptions, and then the poor implementation of what has been planned, after which come the frequent budgetary revisions and ever-worse macroeconomic outcomes. 


\section{IMPAGT OF THE EUROPEAN SEMESTER ON THE BUDGETARY PROGESS IN CROATIA}

When Croatia gets into the EU and accordingly into the European Semester, key changes will come about:

- While drawing up instructions to ministries and other government bodies for the elaboration of strategic plans, which it has to adopt by mid-March, the Ministry of Finance will have to rely on the priorities set out in the Annual Growth Survey, the Alert Mechanism Report and the Employment Guidelines. These documents will since November of the previous year, until February of the current year, have gone through the European Commission, the Council of the EU and the European Parliament.

- So as to be able to supply to the EU from the I5th of April to April 3oth at the latest the national programme of stability and convergence complete with a medium-term budgetary strategy and reform programme as well as a plan for structural reforms aimed at fostering growth and employment, the Government will have to draw up the threeyear strategy not by mid-May, which is the requirement for domestic purposes, but a month earlier.

- In May the EC will evaluate the Croatian national plan and give some concrete recommendations for improvements to be made, and the Ministry of Finance will be able to build these suggestions into the proposal of the guidelines of economic and fiscal policy that it has to submit to the Government by the end of May.

- Up to the middle of June the Government will be able to adopt high-quality guidelines for economic and fiscal policy, which will pay due attention to the evaluations and recommendations of the European Commission of May, and of the Council of the EU of June.

- In July the Council of the EU passes final recommendations for each individual member, and the member is expected to apply them. Hence in July, Croatia - like all the other members - will have to take into consideration the recommendations of the EU that are essential for implementation of the policy mapped out in its instructions for the making and in the actual making of the budget proposal.

The entry of Croatia into the EU and the European Semester will of a certainty have an impact on the timetable and the quality, and also necessarily the transparency, of the plans and the budget in Croatia. A positive effect of these changes will not, of course, depend only on European institutions and processes, but on the interest and commitment of Croatian ministries and of the Government for monitoring and understanding the functioning of European institutions and processes, and prompt incorporation of European instructions and recommendations in Croatian documents.

Even before formal membership, the European Commission invited Croatia to be informally involved in the European Semester, and on April 18, the Government accepted the Economic Programme of the Republic of Croatia for 2IO3, which it will supply to the European Commission. Without going into any detailed analysis of the Programme, from the very first glance it is clear that like all previous Croatian documents it has been produced on over-optimistic assumptions. The Government in its programme looks for a GDP growth of $0.7 \%$ in 2013 and of $2.4 \%$ in 20I4, while the European Commission expects a fall of $0.4 \%$ in 2013 and a rise of only $1 \%$ in 20I4. The IMF expects a fall of $0.2 \%$ in 2013 and a rise of $1.5 \%$ in 2014.

We have started off, then with implausible assumptions that do not take into consideration even the predictions of Croatian economic growth of that very same European Commission to which the Programme is being sent. We shall see, then, how the Programme is going to be judged and what recommendations it will elicit from the EC, the Council of the EU and the European Council. If we understand these recommendations this year with a shrug - for we are only 
informally in the European Semester - in the years to come this will not be possible, because members are expected actually to implement recommendations. Since consistent implementation of recommendations is an essential precondition for financial aid to be given to members who can claim the right because of their excessive deficits and debts - and Croatia already meets the conditions for receiving this aid - one can assume that this will be sufficient motivation for consistent implementation. But at least we have started, and in the years to come one can hope for more realistic, timely and better strategies, plans, programmes and budgets, and a literal implementation of European recommendations. And we would become as a result a country with sounder and more transparent public finances in the long run. 